\title{
Coping strategies in patients with neuropathic pain
}

\author{
Estratégias de enfrentamento em pacientes com dor neuropática
}

Thainá de Oliveira Laluce ${ }^{1}$, Claudia Maria de Luca Colturato Dalul², Marielza Regina Ismael Martins ${ }^{3}$, Rita de Cassia Helu Mendonça Ribeiro ${ }^{4}$, Flavia Cesarino de Almeida 5 , Claudia Bernardi Cesarino ${ }^{4}$

DOI 10.5935/2595-0118.20190046

\section{ABSTRACT}

BACKGROUND AND OBJECTIVES: Chronic neuropathic pain has a multifactorial origin and several coping strategies. The objective of this study was to identify, analyze the different coping strategies for chronic neuropathic pain, relate them with sociodemographic characteristics, pain intensity, and alexithymia. METHODS: A descriptive and cross-sectional study involving 61 patients with neuropathic pain who attended the Pain Clinic from August to December 2017. The instruments used to collect the data of patients with neuropathic pain were a semi-structured interview, the Douleur Neuropathique 4 Questions questionnaire, the Alexithymia Scale, and the Problems Coping Mode Scale.

RESULTS: Of the 61 patients with neuropathic pain, the majority were female, with a mean age of $50.67 \pm 13.12$ years, low schooling, with a spouse, with diseases as the leading cause of pain, positive attitudes to cope with neuropathic pain despite the physical problems such as major changes after pain.

CONCLUSION: The results of the present study allowed us to conclude that the coping strategies of patients with neuropathic pain, according to the application of the Alexithymia Scale and the Problems Coping Mode Scale, that the highest scores were in religious practices, social support and focus on the problem. The alexithymia of this group was higher, especially in the subgroup of men with chronic neuropathic pain.

Keywords: Chronic pain, Coping, Coping strategies, Pain.

Thainá de Oliveira Laluce - (Dhttps://orcid.org/0000-0002-2674-1865;

Claudia Maria de Luca Colturato Dalul - (Dhttps://orcid.org/0000-0003-1518-1695;

Marielza Regina Ismael Martins - (Dhttps://orcid.org/0000-0002-1140-7581;

Rita de Cassia Helu Mendonça Ribeiro - Ohttps://orcid.org/0000-0002-1016-0484;

Flavia Cesarino de Almeida - Dhttps://orcid.org/0000-0001-9797-8117;

Claudia Bernardi Cesarino - (Dhttps://orcid.org/0000-0002-8701-9163.

1. Faculdade de Medicina de São José do Rio Preto, Curso de Graduação em Enfermagem, São José do Rio Preto, SP, Brasil.

2. Faculdade de Medicina de São José do Rio Preto, Curso de Mestrado em Enfermagem, Săo José do Rio Preto, SP, Brasil

3. Faculdade de Medicina de Sáo José do Rio Preto, Departamento de Ciências Neurológicas, São José do Rio Preto, SP, Brasil.

4. Faculdade de Medicina de Săo José do Rio Preto, Departamento de Enfermagem Geral, São José do Rio Preto, SP, Brasil.

5. Fundação Faculdade de Medicina de São José do Rio Preto, Sấo José do Rio Preto, SP, Brasil.

Submitted on July 10, 2018.

Accepted for publication on July 04, 2019.

Conflict of interests: none - Sponsoring sources: BIPIC/CNPq.

Correspondence to:

Avenida Brigadeiro Faria Lima, 5416

15090-000 São José do Rio Preto, SP, Brasil.

E-mail: thainalaluce@gmail.com

(C) Sociedade Brasileira para o Estudo da Dor

\section{RESUMO}

JUSTIFICATIVA E OBJETIVOS: A dor crônica neuropática tem origem multifatorial e apresenta diversas estratégias de enfrentamento. $\mathrm{O}$ objetivo deste estudo foi identificar, analisar as diversas estratégias de enfrentamento de dor crônica neuropática, relacioná-las com as características sociodemográficas, a intensidade de dor e a alexitimia.

MÉTODOS: Estudo descritivo e transversal em que participaram 61 pacientes com dor neuropática que foram atendidos na Clínica da Dor no período de agosto a dezembro de 2017. Para a coleta de dados dos pacientes com dor neuropática foram utilizados os instrumentos: entrevista semiestruturada, o questionário sobre dor neuropática Douleur Neuropathique 4 Questions, a Escala de Alexitimia e a Escala Modos de Enfrentamento de Problemas.

RESULTADOS: Dos 61 pacientes com dor neuropática, a maio-

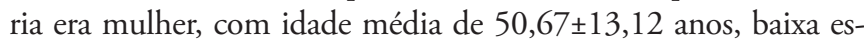
colaridade, com companheiro, doenças como a causa principal da dor, atitudes positivas no enfrentamento da dor neuropática apesar dos problemas físicos como as principais mudanças após a dor.

CONCLUSÁO: Os resultados do presente estudo permitiram concluir que as estratégias de enfrentamento dos pacientes com dor neuropática, de acordo com a aplicação da Escala de Alexitimia e a Escala Modos de Enfrentamento de Problemas, que os maiores escores foram nas práticas religiosas, suporte social e focalização no problema. A alexitimia deste grupo foi maior, especialmente no subgrupo dos homens com dor neuropática crônica. Descritores: Dor, Dor crônica, Enfretamento, Estratégias de enfrentamento.

\section{INTRODUCTION}

Pain causes negative impacts on an individual's life, making it one of the biggest challenges for healthcare professionals. According to the International Association for the Study of Pain (IASP), pain is defined as an unpleasant sensory or emotional experience associated with actual or potential tissue injury ${ }^{1}$.

Pain is classified into two types: acute, which arises from an injury or threat to non-neural tissue. It is usually caused by inflammation, infection, injury, among others; and chronic pain (CP) lasting more than three months or persisting after the usual healing time and not responding to common treatments ${ }^{2}$.

CP can be subdivided into nociceptive, chronic neuropathic pain (CNP), and mixed chronic pain. Nociceptive pain occurs through physiological activation of pain receptors and is related to injury to bone, muscle, or ligament tissues. It commonly responds well to symptomatic treatment with analgesics or non- 
steroidal anti-inflammatory drugs (NSAIDs). CNP is caused by an injury or disease of the somatosensory system and affects 7 to $10 \%$ of the population ${ }^{3}$.

In the treatment of CNP, the challenge happens when the therapies do not have the expected effect, and there is psychological distress caused by the dissatisfaction of the therapeutic plan, leading the individual to look for pharmacological strategies that generate greater financial expense, which may lead to future hospitalization ${ }^{3}$.

In this context, when it comes to pain, there are many variables to consider. However, it is noted in the national and international literature difficulties in the use of the instruments for the assessment of CNP, as well as the comparison of which treatment method is the most appropriate .

Pain is a problem that permeates health services and is an important factor that can impact the patient's ability to go to a health referral center ${ }^{5}$. According to the World Health Organization (WHO), Noncommunicable diseases (NCDs) are the leading causes of mortality and disability in Brazil, impacting the patient, family, health services and the economy due to absence and early retirement ${ }^{5,6}$.

One of the major agents of NCDs is CP, which is present in patients with type 2 diabetes mellitus, cancer, traumatic injuries, and previous strokes ${ }^{7}$. Failure to treat CNP with conventional drugs has a longer duration, and often this pain becomes a disease of its own. These individuals, together with professionals, seek various ways to reduce pain ${ }^{6}$.

Given this situation, this study aimed to identify and analyze the various forms of coping strategies for CNP, relating them to sociodemographic characteristics, pain intensity, and alexithymia.

\section{METHODS}

A descriptive, cross-sectional study with a quantitative approach, conducted at the Pain Outpatient Clinic of the Regional Medical School Foundation of São José do Rio Preto. Sixty-one patients with a medical diagnosis of CNP who attended the Pain Clinic from August to December 2017 participated in this study. When assessing the frequency list of patients with NCD at the Pain Clinic of the last four months, a monthly average of 26 people was obtained. For the sample calculation, the parameters used were $95 \%$ confidence level, $8 \%$ error, and $10 \%$ expected prevalence. Participants were selected by simple random sampling, resulting in 61 patients.

Four data collection instruments were used: the semi-structured interview (sociodemographic and clinical data); the Douleur Neuropathique 4 Questions (DN4) questionnaire (DN screening) ${ }^{8}$; the Alexithymia Scale (TAS) ${ }^{9}$ (measures difficulties to identify and describe feelings); and the Modes of Coping with Problems Scale (EMEP) ${ }^{10}$ (analyzes coping strategies). The $\mathrm{DN} 4^{8}$ pain questionnaire, originally in French, was duly translated and validated into Portuguese and used to identify patients with non-neuropathic and neuropathic pain. The questionnaire consists of 10 items subdivided into two parts: sensory descriptors (seven items) and signs related to the sensory examination (three items). The presence of DN was considered the dependent and necessary variable to reach a score of at least 4 out of 10 , while non-neuropathic pain had scores lower than 4 out of 10 .

The TAS ${ }^{9}$ is a 26-item self-report instrument designed to measure the degree of alexithymia. The items are answered on a five-point Likert scale ranging from 1 (strongly disagree) to 5 (strongly agree). Total scores range from 26 to 130, and in international research, for scores above 74 (inclusive) the subject is considered alexithymic, and under 62 (inclusive) is considered non-alexithymic. For intermediate values, (between 63 and 73) nothing can be said.

The coping strategies used in the face of a general stressor event or a health-related stressor event can be measured using the EMEP, adapted to the Brazilian population by Seidl, Tróccoli and Zannon ${ }^{10}$. It consists of 45 objective questions, 18 problem-focused, 15 emotion-focused, seven seeking religious practice/unrealistic thinking, and five seeking social support. At the end of the scale, there was also a subjective question, aimed at identifying some other coping strategy that was not included in the previous questions. Answers were rated according to the five-point Likert scale: 1- I never do it; 2- I rarely do it; 3- I do it sometimes; 4- I often do it, and 5- I always do it, higher scores indicated greater use of coping strategy. The items are divided into four factors: factor 1: problem-focused coping; factor 2: emotion-focused coping; factor 3: coping centered on the pursuit of religious practices and unrealistic thinking; factor 4: coping based on the search for social support.

The Research Ethics Committee of the Medicine School of São José do Rio Preto (FAMERP) approved this study under CAAE: 62298816.0.0000.5415. All participants signed the Free and Informed Consent Term (FICT).

\section{Statistical analysis}

Data were transferred to a spreadsheet using the Microsoft Excel program, and statistical analysis was performed using analysis of variance (ANOVA) and Tukey multiple comparison tests. The significance level of $p<0.05$ was adopted for the obtained results.

\section{RESULTS}

Table 1 shows the percentage of the sociodemographic and clinical characterization variables of the 61 patients with CNP assessed in the study, in which most of the patients were female (35; 57.38\%), with elementary school (36; $59.02 \%)$, with a partner $(37 ; 61.67 \%)$, had the disease as the cause of pain $(24$; $39.34 \%$ ), reporting physical problems as the main changes after pain $(35 ; 57.38 \%)$ and positive attitude towards neuropathic pain $(42 ; 68.85 \%)$.

The mean age of the patients assessed was $50.67 \pm 13.12$ years old, and a median of 51.00 years old. The coefficient of variation (CV) of this distribution was $25.9 \%$. The minimum age observed was 21.0 years old, and the maximum was 74.0 years old. All patients had DN confirmed by the DN4 when considering the aspects involved in this questionnaire. Pain intensity was $5.1 \pm 1.2$, and the most prevalent sensory descriptors were tin- 
Table 1. Percentage of sociodemographic and clinical characterization variables of patients with neuropathic pain in the Clinic of Pain. São José do Rio Preto/SP, 2017

\begin{tabular}{|c|c|c|}
\hline \multirow[t]{2}{*}{ Variables } & \multicolumn{2}{|c|}{ Patients with neuropathic pain } \\
\hline & $(n=61)$ & $\%$ \\
\hline \multicolumn{3}{|l|}{ Gender } \\
\hline Female & 35 & 57.38 \\
\hline Male & 26 & 42.62 \\
\hline \multicolumn{3}{|l|}{ Education } \\
\hline Elementary school & 36 & 59.02 \\
\hline High school & 15 & 24.59 \\
\hline Higher education & 10 & 16.39 \\
\hline \multicolumn{3}{|l|}{ Marital status } \\
\hline With partner & 37 & 61.67 \\
\hline Without partner & 23 & 38.33 \\
\hline \multicolumn{3}{|l|}{ Cause of pain } \\
\hline Accident & 16 & 26.23 \\
\hline Diseases & 24 & 39.34 \\
\hline Others & 16 & 26.23 \\
\hline Do not know & 5 & 8.20 \\
\hline \multicolumn{3}{|l|}{ Changes after pain } \\
\hline Emotional problems & 26 & 42.62 \\
\hline Physical problems & 35 & 57.38 \\
\hline \multicolumn{3}{|c|}{ How do you deal with the pain } \\
\hline Negative attitude & 19 & 31.15 \\
\hline Positive attitude & 42 & 68.85 \\
\hline
\end{tabular}

gling (52\%) and burning (28\%). Regarding the physical signs related to sensitivity, hypoesthesia to the touch was the predominant one (62\%).

Regarding the age group $(\mathrm{p}=0.049)$ and the way patients deal with pain $(\mathrm{p}=0.007)$, there were significant differences in DN scores. Regarding the age group, patients aged up to 59 years old had significantly higher DN scores compared to patients aged 60 years old or older, that is, the DN score was higher for adults when compared to the elderly. Regarding patients' attitude towards pain, patients with negative attitudes had a significantly higher DN score than patients with positive attitudes toward pain.

According to the TAS, on average, patients were alexithymic, because the average score was over 74 points, showing that patients with CNP have significant difficulties in expressing their emotions, feelings, and body sensations. There were significant differences regarding gender $(\mathrm{p}=0.034)$ and changes after pain $(\mathrm{p}=0.040)$. The men's average alexithymia score was significantly higher than the women's score, and physical problems were responsible for determining higher alexithymia in patients with CNP (Table 2).

The results of the application of EMEP for CNP patients had factor 2 (focusing on emotion) as the lowest score when compared to the other factors, assuming that CNP patients do not focus so much on emotion to overcome the pain problem (Table 3$)$.
Table 2. Descriptive statistics of alexithymia scores for patients with neuropathic pain

\begin{tabular}{|c|c|c|c|c|}
\hline Descriptive statistics & $\mathrm{n}$ & Mean \pm SD & Median & $\mathrm{p}$-value \\
\hline Alexithymia (general) & 61 & $77.89 \pm 9.41$ & 80.00 & \\
\hline \multicolumn{5}{|l|}{ Gender } \\
\hline Female & 35 & $75.86 \pm 11.05$ & 79.00 & \multirow[t]{2}{*}{$0.034^{1}$} \\
\hline Male & 26 & $80.62 \pm 5.73$ & 82.50 & \\
\hline \multicolumn{5}{|l|}{ Age group (years old) } \\
\hline Up to 59 & 44 & $78.50 \pm 9.02$ & 81.50 & \multirow[t]{2}{*}{$0.451^{1}$} \\
\hline 60 or more & 17 & $76.29 \pm 10.49$ & 79.00 & \\
\hline \multicolumn{5}{|l|}{ Marital status } \\
\hline With partner & 38 & $79.00 \pm 8.65$ & 81.00 & \multirow[t]{2}{*}{$0.262^{1}$} \\
\hline Without partner & 23 & $76.04 \pm 10.49$ & 78.00 & \\
\hline \multicolumn{5}{|l|}{ Education } \\
\hline Elementary school & 36 & $79.25 \pm 7.13$ & 80.00 & \multirow[t]{3}{*}{$0.061^{2}$} \\
\hline High school & 15 & $78.87 \pm 10.59$ & 82.00 & \\
\hline Higher education & 10 & $71.50 \pm 12.81$ & 73.00 & \\
\hline \multicolumn{5}{|l|}{ Cause of pain } \\
\hline Accident & 16 & $79.75 \pm 10.91$ & 82.50 & \multirow[t]{4}{*}{$0.511^{2}$} \\
\hline Disease & 24 & $77.88 \pm 7.58$ & 77.50 & \\
\hline Others & 16 & $80.60 \pm 4.45$ & 80.00 & \\
\hline Do not know & 5 & $75.19 \pm 11.30$ & 78.00 & \\
\hline \multicolumn{5}{|l|}{ Changes after pain } \\
\hline Emotional problems & 26 & $74.81 \pm 11.36$ & 78.00 & \multirow[t]{2}{*}{$0.040^{1}$} \\
\hline Physical problems & 35 & $80.17 \pm 6.99$ & 82.00 & \\
\hline \multicolumn{5}{|c|}{ How do you deal with the pain } \\
\hline Negative attitude & 19 & $76.42 \pm 11.90$ & 81.00 & \multirow[t]{2}{*}{$0.486^{1}$} \\
\hline Positive attitude & 42 & $78.55 \pm 8.12$ & 79.50 & \\
\hline
\end{tabular}

${ }^{1} p$-value for t-test for independent samples at $p<0.05 ;{ }^{2} p$-value referring to the Analysis of Variance (ANOVA) test at $p<0.05$.

Table 3. Descriptive statistics of EMEP scores in patients with neuropathic pain. São José do Rio Preto/SP, 2017

\begin{tabular}{|c|c|c|c|c|}
\hline Factors & $n$ & $\begin{array}{c}\text { Mean } \pm \\
\text { standard } \\
\text { deviation }^{2}\end{array}$ & Median & $p$-value ${ }^{1}$ \\
\hline Focusing on problem & 61 & $3.34 \pm 0.58 \mathrm{a}$ & 3.38 & $<0.001$ \\
\hline Focusing on emotion & 61 & $2.75 \pm 0.71 b$ & 2.73 & \\
\hline Religious practices & 61 & $3.45 \pm 0.75 \mathrm{a}$ & 3.57 & \\
\hline Social support & 61 & $3.15 \pm 3.40 \mathrm{a}$ & 3.40 & \\
\hline
\end{tabular}

${ }^{1} \mathrm{p}$-value referring to the Analysis of Variance (ANOVA) test at $\mathrm{p}<0.05 .{ }^{2}$ Different letters in the same column differ from each other by Tukey's multiple comparison test at $p<0.05$.

As only factor 2 presented a significant difference, the score of this factor was assessed according to the sample characterization variables (Table 4).

According to factor 2 analysis in relation to the characterization variables, there were no cases of significant differences, assuming that the assessed variables did not influence the focusing of emotion to deal with neuropathic pain. 
Table 4. Descriptive statistics of factor 2 scores (focusing on emotion) according to EMEP for patients with neuropathic pain. São José do Rio Preto/SP, 2017

\begin{tabular}{|c|c|c|c|c|}
\hline Descriptive statistics & $\mathrm{n}$ & Mean \pm SD & Median & $p$-value \\
\hline \multicolumn{5}{|l|}{ Gender } \\
\hline Female & 35 & $2.76 \pm 0.71$ & 2.73 & $0.833^{1}$ \\
\hline Male & 26 & $2.72 \pm 0.72$ & 2.73 & \\
\hline \multicolumn{5}{|l|}{ Age group (years old) } \\
\hline Up to 59 & 44 & $2.84 \pm 0.67$ & 2.80 & $0.120^{1}$ \\
\hline 60 or more & 17 & $2.50 \pm 0.76$ & 2.46 & \\
\hline \multicolumn{5}{|l|}{ Marital status } \\
\hline With partner & 38 & $2.88 \pm 0.69$ & 2.86 & $0.054^{1}$ \\
\hline Without partner & 23 & $2.52 \pm 0.69$ & 2.53 & \\
\hline \multicolumn{5}{|l|}{ Education } \\
\hline Elementary school & 36 & $2.76 \pm 0.75$ & 2.73 & $0.601^{2}$ \\
\hline High school & 15 & $2.84 \pm 0.76$ & 2.73 & \\
\hline Higher education & 10 & $2.55 \pm 0.49$ & 2.60 & \\
\hline \multicolumn{5}{|l|}{ Cause of pain } \\
\hline Accident & 16 & $2.94 \pm 0.61$ & 2.80 & $0.185^{2}$ \\
\hline Disease & 24 & $2.65 \pm 0.79$ & 2.73 & \\
\hline Others & 16 & $2.56 \pm 0.61$ & 2.60 & \\
\hline Do not know & 5 & $3.21 \pm 0.76$ & 3.46 & \\
\hline \multicolumn{5}{|l|}{ Changes after pain } \\
\hline Emotional problems & 26 & $2.83 \pm 0.67$ & 2.86 & $0.420^{1}$ \\
\hline Physical problems & 35 & $2.68 \pm 0.74$ & 2.66 & \\
\hline \multicolumn{5}{|c|}{ How do you deal with the pain } \\
\hline Negative attitude & 19 & $2.66 \pm 0.81$ & 2.66 & $0.571^{1}$ \\
\hline Positive attitude & 42 & $2.78 \pm 0.66$ & 2.73 & \\
\hline
\end{tabular}

${ }^{1} p$-value referring to $t$-test for independent samples at $p<0.05 .{ }^{2} p$-value referring to the Analysis of Variance (ANOVA) test at $p<0.05$.

\section{DISCUSSION}

Of the 61 patients with CNP, most had low education, lived with a partner, diseases as the main cause of pain, coping with CNP positive attitudes, despite physical problems as the main changes after pain. Another point observed is that most were female. This finding is in line with other studies, where the majority affected by $\mathrm{CP}$ were women compared to men. In addition, females were more frequent in absences and medical seeking. In this study, the mean age was $50.67 \pm 13.12$ years old. The population of the institute who reported suffering from $\mathrm{CP}$ had a median of 35.5 years old, showing that $\mathrm{CP}$ is increasingly affecting the young adult population $^{11,12}$.

When the variables were crossed, no significant differences were observed regarding the coping of these patients regarding gender, marital status, education, cause of pain, and changes after pain.

Nevertheless, there was a statistically significant difference regarding age and the way to deal with pain. These results differ from the results of the study ${ }^{13}$ that assessed the patients with CNP due to traumatic spinal cord injury, performed in two institutions in the city of Sáo Paulo, where most were male, aged between 30 and 39 years old. This study observed results similar to the findings of this study in which the patients assessed with CNP did not have significant differences regarding marital status, education, gender, cause of pain, and changes after pain.

Regarding the age group, this study found that young people and adults had higher CNP scores when related to the elderly, who have a better attitude towards pain, possibly because they believe this symptom is natural to the physiological process of aging and associated chronic comorbidities. Thus, it is more challenging to obtain real results when this item is assessed, which may generate erroneous results, and hinder an adequate therapeutic approach ${ }^{14}$.

In a study conducted with patients from Canada, Denmark, India, and Taiwan ${ }^{15}$, it was observed that individuals who had more significant depression and catastrophization had greater intensity of pain and comorbidities, corroborating the results found in this study, in which individuals who tend to think negatively experience greater pain intensity, thus helping the development of depression and anxiety ${ }^{15}$.

This study observed that most men with CNP had alexithymia; that is, they may have greater difficulty in communicating their body emotions and feelings to others when compared to women. Regarding changes after pain, physical problems were statistically relevant when compared to emotional ones. Given this, alexithymia was significantly related to factor 3, which are religious practices/unrealistic thinking. The results of this study disagree with research on chronic renal patients undergoing hemodialysis, who had no alexithymia, which may be justified by the continuous psychological support during their treatment ${ }^{16}$.

In the case of alexithymia, a higher prevalence was observed in males. Corroborating the present results, a research was conducted $^{17}$ at the University of Porto, in Portugal, which found higher scores in men with greater difficulty in describing feelings, highlighting the Normative Male Alexithymic Theory. This theory holds that men in their childhood are discouraged from expressing and talking about their feelings and emotions. Thus, a higher score for physical changes after the pain is noted in these patients, affirming man's social creation process.

Many have a psychosocial impairment, and through spirituality, they can have positive thoughts and feelings, more easily cope with difficult situations and a better look at everyday situations ${ }^{18}$.

Longitudinal research on pain coping strategies in patients during the first year after spinal cord injury found that psychosocial factors and pain coping strategies correlated with pain intensity and discomfort, that is, pain disrupts their life and has negative impact ${ }^{19}$.

Emotion-focused coping refers to people's attempt to regulate the emotional response that has been generated by the stressful pain situation and is often used when a problem is uncontrollable, and some behavioral or cognitive strategies can be used such as excessive alcohol use, tobacco, drugs, excessive 
physical exercise, escape, problem minimization, distancing and selective attention ${ }^{20}$.

In this study, the application of EMEP in the 61 patients with CNP obtained the highest scores on religious practices, social support, and focusing on the problem.

Regarding religious practices, the results are in agreement with a study that observed that the incorporation of spirituality has relevance and recognition as an indicator of health, in the search for the promotion of comprehensive care and for portraying the already known profile of Brazilians related to religiosity ${ }^{20}$. Similar results were also found in research on coping with pain, in which religiosity and spirituality were associated with the control of stress involved in the pain process ${ }^{21}$.

Social support had the second-highest score by patients with CNP and indicated the search for support in the health system, highlighting the importance of quality and availability of the health sector to help such patients. A review study of the psychosocial, intrapsychic, psychiatric, and psychobehavioral factors that influence the nature, severity, and persistence of the neuropathic pain found that social support is an important component to control and manage the active participation of patients in their healthcare in relation to pain ${ }^{22}$.

Focusing on the problem was the third-highest score, and this factor indicates the portion of the rationality of patients who focus on understanding the problem. A literature review study highlights that CNP is a serious world public health problem, being considered a chronic disease whose management in the control of CNP is still inadequate ${ }^{23}$.

In contrast, the factor of focusing on emotion was the one with the lowest score, assuming that patients with CNP do not use emotion to overcome the pain problem, and this factor was the only one that showed a significant difference, having been assessed according to sample characterization variables.

It can be said that these are practices with a great cultural focus, corroborating the books and research by David Le Breton, a French anthropologist, and sociologist who devoted a portion of his studies to pain. He concluded that the pain is intimate with each other, but its basis is usually in culture, society, relationships, and education, and thus the social bond. It is therefore present, both in body expression and in the impression that each individual has ${ }^{24}$.

Some researchers point out that the most commonly used strategy for coping with $\mathrm{CD}$ is a religious activity, and stress can be controlled by acting on the hypothalamus-pituitary-adrenocortical ${ }^{25}$. Improvement in mental health indicators is also proven, as well as better adaptation to stress and greater encouragement in daily life with religious practice ${ }^{26}$. However, the physiological effect of religious practices on their physical symptoms in pain control has not been proven ${ }^{27}$. Regarding CP, another study conducted with 281 patients observed an association between pain coping strategies and mood measures in relation to health functioning ${ }^{28}$.

There is a search for psychoeducational programs coordinated by psychologists through texts, lectures, demonstrations, training, relaxation techniques, problem-solving, encouraging, and creating pain-coping strategy ${ }^{29}$.

Thus, health professionals need to develop care holistically, valuing not only the religiosity but also the spirituality of the patient, regardless of creed or religious beliefs, thus contributing to their well-being, coping with the disease and improving the quality of life ${ }^{30}$.

\section{CONCLUSION}

This research found a relationship between alexithymia and chronic neuropathic pain. The prevalence of this phenomenon was higher among men. What is the nature of this complex relationship, how the predisposing and triggering factors of the alexithymia phenomenon would act are questions that need further investigation The highest coping strategies scores for patients with chronic neuropathic pain, according to the application of EMEP, were religious practices, social support, and focusing on the problem. Thus, it can be concluded that these factors are important in terms of this clash between the body and mind, helping in the process of higher physical and mental quality of life.

\section{REFERENCES}

1. Merskey H, Bogduk N. Classification of chronic pain. 2nd ed. Seattle: IASP Press; 1994.

2. Brasil. Ministério da Saúde. Portaria no 1.083, de 02 de outubro de 2012. Aprova o Protocolo Clínico e Diretrizes Terapêuticas da Dor Crônica. Diário Oficial da União. Brasilia, DF, de 03 de outubro de 2012. Seção 1:54-58.

3. Almeida FC, Castilho AC, Cesarino CB, Ribeiro RC, Martins MR. Correlation between neuropathic pain and quality of life. BrJP. 2018;1(4):349-53.

4. Oliveira RM, da Silva LM. Chronic pain related to AIDS: perspective of nurses and doctors. Rev Bras Enferm. 2014; 67(1):54-61.

5. Organização Pan Americana de Saúde. Governos devem intensificar esforços para o combate às doenças crônicas não transmissíveis. Disponível em:https://www.paho. org/bra/index.php?option=com_content\&view=article\&id=5495.Acesso em : $12 \mathrm{de}$ dezembro de 2018.

6. Cardoso MG, Weinstock JG, Sardá Júnior J. Adesāo ao tratamento da dor neuropática. Rev Dor. 2016;17(Suppl 1):S107-9.

7. Dermanovic Dobrota V, Hrabac P, Skegro D, Smiljanic R, Dobrota S, Prkacin I, et al. The impact of neuropathic pain and other comorbidities on the quality of life in patients with diabetes. Health Qual Life Outcomes. 2014;12:171.

8. Santos JG, Brito JO, de Andrade DC, Kaziyama VM, Ferreira KA, Souza I, et al. Translation to Portuguese and validation of the Douleur Neuropathique 4 questionnaire. J Pain. 2011;11(5):484-90.

9. Yoshida EMP. Toronto alexithymia scale-TAS: precisão e validade da versão em português. Psicol Teor Pratic. 2000;2(1):59-74.

10. Seidl EM, Tróccoli BT, Zannon CL. Análise fatorial de uma medida de estratégias de enfrentamento. Psic: Teor e Pesq. 2001;17(3):225-34.

11. Posso I, Palmeira C, Vieira E. Epidemiology of neuropathic pain. Rev Dor 2016;17(Suppl 1):11-4.

12. 12.Vasconcelos F. Dor crônica em trabalhadores de uma instituiçấo de ensino do Tocantins: prevalência e fatores associados [dissertaçấo de mestrado]. Universidade Federal do Tocantins; 2017

13. Lami MJ, Martínez MP, Miró E, Sánchez AI, Guzmán MA. Catastrophizing, acceptance, and coping as mediators between pain and emotional distress and disability in fibromyalgia. J Clin Psychol Med Settings. 2018; 25(1):80-92.

14. Oliveira CH, Martins EA, Montezeli JH, Souza TG, Dellaroza MS. Understanding the experience of older people with chronic pain: the light of Callista Roy's theory. Ciênc Cuid Saúde. 2017;16(1):1-9.

15. Muere A, Tripp DA, Nickel JC, Kelly KL, Mayer R, Pontari M, et al. Depression and coping behaviors are key factors in understanding pain in interstitial cystitis/bladder pain syndrome. Pain Manag Nurs. 2018;19(5):497-505.

16. Vides MC, Martins MR. Bone pain assessment in patients with chronic kidney disease undergoing hemodialysis. Rev Dor. 2017;18(3):245-9.

17. Freire L. Alexitimia: dificuldade de expressão ou ausência de sentimento? Uma análise teórica. Psic: Teor e Pesq. 2010;26(1):15-24

18. Taylor J, Huelbes S, Albu S, Gómez-Soriano J, Peńacoba C, Poole HM. Neuropathic pain 
intensity, unpleasantness, coping strategies, and psychosocial factors after spinal cord injury: an exploratory longitudinal study during the first year. Pain Med. 2012;13(11):1457-68.

19. Pereira TB, Rodrigues VL. As estratégias de coping na promoção à saúde mental de pacientes oncológicos: uma revisão bibliográfica. Rev Psicol Saúde. 2016;8(1):24-31.

20. Borges MS, Santos MB, Pinheiro TG. Social representations about religion and spirituality. Rev Bras Enferm. 2015;68(4):609-16.

21. Rizzardi CD, Teixeira MJ, Siqueira SR. Espiritualidade e religiosidade no enfrentamento da dor. Mundo da Saúde. 2010;34(4):483-7.

22. Van Der Lugt CM1, Rollman A, Naeije M, Lobbezoo F, Visscher CM. Social support in chronic pain: development and preliminary psychometric assessment of a new instrument. J Oral Rehabil. 2012;39(4):270-6.

23. Perissinotti DM, Portnoi AG. Aspectos psicocomportamentais e psicossociais dos portadores de dor neuropática. Rev Dor. 2016;17(Suppl 1):S79-84.

24. Fonseca PR, Gatto BE, Tondato VA. Neuropatia dolorosa pós-traumática e pós-operatória. Rev Dor. 2016;17(Suppl 1):S59-62.
25. Andrade MR. Dor Crônica na Atenção Primária - Um Problema de Saúde Pública [Trabalho de Conclusão de Curso]. Juiz de Fora (MG): Universidade Federal de Minas Gerais; 2014.

26. Siqueira D, Costa B, Figueiredo A. Coping e qualidade de vida em pacientes em lista de espera para transplante renal. Acta Paul Enferm. 2017;30(6):582-9.

27. Aquarone RL. Dor neuropática: implicaçóes na qualidade de vida de pessoas com lesăo medular [Dissertação]. São Paulo: Universidade de Săo Paulo, Escola de Enfermagem; 2013

28. Baastrup S, Schultz R, Brødsgaard I, Moore R, Jensen T, Vase Toft L et al. A comparison of coping strategies in patients with fibromyalgia, chronic neuropathic pain, and pain-free controls. Scand J Psychol. 2016;57(6):516-22.

29. Pinheiro R, Uchida R, Mathias L, Perez M, Cordeiro Q. Prevalência de sintomas depressivos e ansiosos em pacientes com dor crônica. J Bras Psiquiatr. 2014;63(3):213-9.

30. Menezes TM. Dimensấo espiritual do cuidado na saúde e enfermagem. Rev Baiana Enferm. 2017:31(2):e22522. 